\title{
Kellogg Funded Education and Career Information Centers In Public Libraries
}

\author{
Joan C. Durrance \\ University of Michigan, Ann Arbor
}

A series of generous grants by the W.K. Kellogg Foundation to public libraries in several states (first in New York, and later in Pennsylvania, Michigan, Nebraska, and Washington) has in the last several years resulted in the creation of a number of education, job, and career information centers. These centers have enriched services in libraries by bringing librarians in direct contact with other professionals, most notably career counselors and adult educators, and by making available to library users interactive career counseling software and career guidance services.

There is a great range of professional practice subsumed in these Kellogg funded education information centers (EICs). These centers, usually start with a very strong materials collection, interactive software packages, and information services needed to support the needs of job seekers and career changers. Most EICs, known by such names as Job and Career Information Center, Work Place, Work World, and Education Information Center, provide extensive client centered activities which include advisement and counseling regarding the job seeking/career change process. At some sites there are career counselors working at the library; at others librarians refer clients to the services of career counselors.

These services have provided badly needed, free assistance to citizens in well over a hundred communities in the funded states. Their success has been due to several factors: their design-which focuses on the needs of the individuals, a well designed training package, a community based approach which involves working closely with ap-

Joan C. Durrance is an Associate Professor in the School of Information and Library Studies at the University of Michigan, Ann Arbor, Michigan 49109. 
propriate agencies in the community, and a willingness on the part of public library directors to experiment with new modes of public library service.

\section{Design}

EIC practice in many, but not all sites, includes as a major component at least one interactive computer program which focuses on career decision making; often there is a career assessment program such as DISCOVER or SIGI PLUS and an occupational information system (OIS) designed around a specific state's resources and needs. In addition, most EICs have wordprocessing, resume writing, and other software and one or more computers. Sites which lack these sophisticated computer career assessment programs focus more on such client centered activities as resume writing assistance.

Computers at the busy sites are in use most of the time. Therefore, in many centers walk-in use is impossible. DISCOVER, SIGI PLUS, and other career assessment software usually require a minimum of an hour of uninterrupted time. Thus, the computer software coupled with the nature of the need have combined to produce a practice pattern which may mean that the client-rather than just dropping in, getting served, and leaving-will make an appointment for the first convenient time that works for both the client and the EIC staff. This appointment may be: to use the software, to get assistance on how to use the software, to go over a resume with an EIC staff member, for a diagnostic or needs assessment interview, or for a career advising appointment. In busy centers, appointments for both staff time and for computer time are the norm.

Because of the similar nature of many questions, some EICs have developed programs and workshops which are repeated at regular intervals. Usually these programs, on resume writing, the job search process, interviewing, etc., are conducted by a variety of individuals from various community agencies.

There is a wide range of intervention strategies used. These may include the diagnostic interview which focuses on the nature of need; information provision; a helping interview which focuses on facilitating various actions of the client; career advisement which includes discussion of the nature of the process and the variety of careers, including interpreting computer printouts; training and instruction (about materials, computer programs, interviewing, job search process, etc.); and referral to other agencies. Due to the nature of these 
services, some staff have made alterations in the library environment to provide, when appropriate, more privacy than is usually found in a public library reference area.

Three ancedotes can serve to illustrate how people have come to use these library based education, job and career information centers.

\section{Mary}

Mary, a forty-year-old woman, first visited the EIC in her local library on a tour with the local Displaced Homemaker Program. She had not worked outside the home for several years. Most recently she had been a school busdriver, a job she didn't really like and one that had no fringe benefits. Some years earlier she had worked as a clerk/receptionist. She was quite anxious to find a job. She later returned a number of times. While at the library she used SIGI PLUS, an interactive career guidance computer program, quite a few times, consulted other career counseling materials, discussed her options with library staff, and was referred to a career counselor. As a result of her sessions at the "EIC", she obtained a job as a clerk typist and developed plans to take a course in travel and tourism.

\section{Raoul}

Raoul is a young Hispanic with a wife and child to support. Not too long before coming to this country from Mexico, Raoul graduated from college with an engineering degree. Unable to find a job that utilized his skills, Raoul had worked in a series of low-paying, menial jobs. His English-language skills were poor, and he had very little confidence, and limited knowledge about how to find a job. At his local library's EIC where a counselor was available to work with him, Raoul learned how to relate his background to finding a job. At the same time he worked with a librarian to identify appropriate information and materials designed to help him prepare his resume and to interview more effectively. The EIC staff at the library helped Raoul structure a job strategy and referred him to a local agency that helped minorities find employment. In just two weeks, Raoul found a job in an engineering company that had other Spanish-speaking employees. Shortly after that, he let the staff know that he was very pleased with his new job and that he had begun on his own to plan for continuing education.

\section{Cindy}

When the local glass factory closed, Sally, the librarian at the Kellogg funded job center and career center in a western Pennsylvania public library went to the factory and gave a seminar on job seeking skills. She told those that she talked with that if they came to the library they could use the computer which was equipped with a career advising program, they could check out materials on careers, and they might, as well, talk with the library staff about the process of retraining to get a new job. 
One person who took the librarian up on her offer was Cindy, a 32 year old single parent with a high school education, who lost her job when the factory closed. Cindy had been back a number of times over the intervening months. Over a period of six months Sally worked with her using DISCOVER and Pennsylvania Careers software, showed her how to get financial aid information, and provided her with encouragment. During that time Cindy decided that she wanted to go to college. After expressing her concern about the feasibility of enrolling as a freshman at her age, she enrolled in a small college in the next community. Throughout her transition from laid off worker to college student, the librarian gave her encouragment, guidance, and information.

\section{Training}

These innovative public library services required an ambitious training program which was generously provided by the W.K. Kellogg Foundation. These services in some libraries built on existing services designed to provide information to job seekers and career changers. Other libraries were simply responding to perceived needs in their communities. However, in all libraries, the staff were venturing into new territory, and training in career counseling techniques was an important element in the effective development of the services. An audit of training needs conducted by this author incorporated the concerns of librarians who were initiating these services into an extensive training program developed by Cynthia Johnson discussed in the next article by Sampson.

Staff needed to learn more about: conducting different types of interviews effectively; reference, assessment, and career counseling; the world of work; resources which can be used to help people; and what people go through as they are in the transition process. They needed to learn more about how to provide support and encouragement needed by job seekers and career changers. They felt it important to increase their skills in making appropriate referrals to resources outside the library.

Johnson's extensive experience in career counseling and training resulted in a training program designed to give librarians the knowledge needed to understand the decision needs of adults in transition and to work with them through the transition process, to understand the nature of career counseling, to gain the ability to work with career counseling software, and to learn when and how to refer their clients to career counselors. Given major differences in the programs 
in participating states, Johnson tailored the training for each participating state. Her training has been supplemented by state based programs and continuing education programs at annual meetings of the American Library Association.

As a result of the training they have received and the "bootstrap" process of learning on the job, many of these staff have become knowledgeable about career decision-making and planning, the job search process, small business development, and the educational and workrelated resources of the community.

\section{Interaction With Community Agencies}

These are community centered services and require librarians to interact with a variety of educational, social service, and employment services. Other professionals in communities served by libraries which provide these services have come to realize that libraries can facilitate the role that their agency plays in the community by taking advantage of the ability of librarians to find, organize and disseminate information. Testimonials from agency heads illustrate this new understanding of what the library can do for them:

"My agency is always looking for new resources. I couldn't possibly research all that I need to. The library provides the information we don't have the time and expertise to obtain.";

"The library made us more aware of what other agencies have to offer."

More and more community agencies are sending their clients to the local public library for information and assistance that just isn't available other places. Librarians regularly get notes from agency staff who in the past had completely underestimated or misunderstood the role that the library plays in the community.

"My eyes have been opened. The Library has become a focal point in this community."

"The community now thinks of the Library as more than just books . . it is a place to get real and needed 'life' information."

"I was surprised that the library has so much to offer." 


\section{Experimentation with Staff and Services}

Public library directors have shown their willingness to experiment in a variety of ways with staffing and services. Some library directors such as those in three communities in Washington: Longview, Ever-ett, and Spokane, and several New York sites hired career counselors (or individuals who were in the process of getting their counseling degrees) to run their services. Some sites in New York and Nebraska have made career counselors available at the libraries at certain times or on call. Libraries in most of the sites have used counselors in workshops they provided on specific career decision making topics.

Library managers, in several communities, including those in Flint and Lansing, Michigan hired other professionals, including adult educators and social workers, to develop the programs in their centers. Since these are experimental services, there is no one model. As these services come to the end of their Kellogg funding period, it is time to examine the longevity of professionals other than librarians in these positions. In New York, many counselors have remained well past the initial Kellogg funding period.

The future is optimistic for these experimental services in public libraries. The positive experience of pioneering staff bodes well for adoption of these services by other public libraries. The Kellogg Foundation saw public libraries as logical homes for EICs because libraries "are accessible to every element of the population and perceived as neutral, consumer-oriented, and non-threatening."

\section{The Future}

Over a decade the Kellogg Foundation provided millions of dollars to start EICs in a number of states. The experiment has spread to a number of other communities in the states where Kellogg invested in EICs. In an effort to facilitate adoption by still other libraries, Kellogg has recently provided a generous grant to the American Library Association to create a guide to the development of these services.

This guide is being written by the author of this article, a faculty member at the University of Michigan who has observed service in over 40 EICs in four states.

The new guide, to be published in mid 1991, builds on a decade of public library experience in providing these services. It will be part of 
a series of guides to planning and developing public library services sponsored by the Public Library Association and published by the American Library Association. It will assist library decision-makers across the nation to develop new ways that their libraries can better serve job seekers, career changes, and other patrons in need of problem-solving assistance. 